\title{
BOWING AND SCRAPING IN THE ANCIENT NEAR EAST: AN INVESTIGATION INTO OBSEQUIOUSNESS IN THE AMARNA LETTERS
}

ELLEN F. MORRIS, Columbia University

\section{INTRODUCTION}

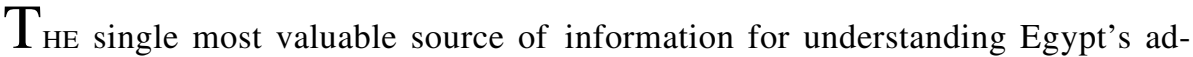
ministration of its northern empire during the Amarna period is a corpus of roughly 350 cuneiform tablets, known collectively as the "Amarna letters." These documents, which come mostly from an archive found at Tell el-Amarna in the 1880s, were exchanged between the Egyptian court and Near Eastern rulers of polities both large and small. Although the chronology is still debated, the letters are thought to span a period of at most three decades in the latter half of the fourteenth century B.C.- between the 32nd year of Amenhotep III and the 4th year of Tutankhamun. ${ }^{1}$

While certain aspects of these letters have been extensively studied, their potential to illuminate the internal structure of the empire at this time has by no means been exhausted. As I hope to demonstrate herein, the results of a systematic study of the greeting formulas used by Egypt's vassals when addressing the pharaoh can reveal a great deal about the varying degrees of political control within the Egyptian empire. After a brief description of the methodology employed in this study, I will discuss the clustering in social rank that I believe is discernible among the different geographic areas of Egypt's northern empire. Whether these proposed rankings may potentially shed light on the preparation of individual treaties between the Egyptian state and particular vassals is the subject of the concluding section of this article.

\section{Methodology}

Greeting formulas are preserved in 207 of the letters sent from Syro-Palestinian vassals to the Egyptian king. All of these formulas (with the exception of 31 composed by RibHadda of Byblos, which are slightly anomalous and hence not included in the study) exhibit a consistent tripartite structure. The letters begin with a statement of address, which can vary from the relatively straightforward "Say to the king of Egypt" (EA 52) to the elaborately obsequious "Say to the king, my lord, my Sun, my god, the Sun from the sky" (EA 235). The second element is a declaration of the sender's identity, which likewise ranges from

[JNES 65 no. 3 (2006)]

(C) 2006 by The University of Chicago.

All rights reserved.

0022-2968-2006/6503-0002\$10.00.

\footnotetext{
${ }^{1}$ For background on the Amarna archive and a complete translation of the letters, see W. L. Moran, The Amarna Letters (Baltimore, Maryland, 1992). All translations of individual Amarna letters found in this article are Moran's and are cited by the $(\mathrm{EA}=\mathrm{El}$ Amarna) number of the letter itself. In table 2, p. 182 below, GN is used as an abbreviation for "geographical name." Uncertain translations/restorations are in italics.
} 
"Message of the king of [Such-and-Such]" (EA 227) to "Message of [So-and-So], your servant, the dirt at your feet and the ground you tread on, the chair you sit on and the footstool at your feet" (EA 195). Finally, the address ends with an imagined prostration by the sender before the pharaoh himself. The most dignified of these is "I fall at the feet of my lord" (EA 227). Whereas the prostration may again be as servile as "I indeed prostrate myself at the feet of the king, my lord, my god, my Sun, the Sun from the sky, seven times and seven times, on the back and on the stomach" (EA 314).

My aim in investigating these greeting formulas was to try to determine the factors that might govern an individual vassal's choice of introduction. Was a particularly groveling greeting, for instance, simply a matter of lickspittling on the part of the vassal, or was there involved an actual ranking of polities within the empire, which might in turn reflect a more concrete differentiation of the obligations and/or rights accorded to each? In order to address this question within the confines of a relatively short article, some oversimplification is unavoidable and perhaps even desirable, given the dizzying array of variables inherent in the sample. The findings I will offer are therefore broad in outline, but the patterns produced are nonetheless significant.

In terms of methodology, each of the three sections of a letter's greeting formula was given its own ranking on a scale from 1 to 5 -with 1 being only a touch obsequious and 5 being dramatically so. For the most part, this division progressed logically corresponding to the number of titles of the king, the number of epithets of the sender, or the degrees of prostration of the individual before his lord. In certain cases, however, as in whether falling beneath the feet of the king was a degree lower than simply falling at the feet of the king, judgment calls had necessarily to be made. All in all, however, the system worked remarkably well, and the results are laid out for the reader in tables 1-3 (see below).

Each letter thus yielded its own composite ranking taken from the average of the three sections of the greeting. These composite scores were then themselves averaged to give a final rank for each city (see table 4). Although this method is, indeed, most unsubtle, such a ranking of the polities produces four main clusters. These clusters, in turn, correspond quite closely to distinct geographic areas, namely (and in ascending order of obsequiousness), the northern frontier of the empire, the southern hill country, the Phoenician coast taken together with northern Canaan, and lastly, as well as leastly, the coastal lowlands of Canaan and the Shephelah (see the map presented in fig. 1 below). ${ }^{2}$

\section{Egypt's NeAR EAStern VAsSals}

\section{The Northern Frontier}

On the outermost fringe of the Egyptian empire were the polities of Nuhasse, Ugarit, Qatna, Tunip, and Irqata. Judging from the contents of the Amarna letters and from outside historical sources, not only were these areas located at the very extremity of the region Egypt could claim - however disingenuously - to control, but most were also under threat from or acting in consort with the newly powerful Hittite kingdom in Anatolia. Just to

\footnotetext{
2 Given the importance of geography to this study, only letters of localizable provenience have been analyzed.
} 


\section{TABLE 1}

\section{First Section of the Greeting Formula}

\begin{tabular}{|c|c|c|}
\hline 1 point & Say to the king of Egypt & Qatna (EA 52) \\
\hline \multirow[t]{2}{*}{2 points } & $\begin{array}{l}\text { (Say) to the king, } \\
\text { my/our lord }\end{array}$ & $\begin{array}{l}\text { Hazor (EA 227-28); Tunip (EA 59); Damascus (EA 194-96); Kadesh } \\
\text { (EA 189); Ruhizza (EA 191); Amurru (EA 63-65); Irqata (EA 100); Byblos } \\
\text { (EA 90, 118, 125-26, 129-30, 136, 362); Jerusalem (285-87, 289-90); } \\
\text { Shechem (EA 252); Ginti-Kirmil (EA 264-65); Qiltu (EA 284, 335); Tyre } \\
\text { (EA 153-54); Lachish (EA 330) }\end{array}$ \\
\hline & $\begin{array}{l}\text { (Say) to the son of the } \\
\text { Sun, my lord }\end{array}$ & Qatna (EA 53, 55) \\
\hline \multirow[t]{5}{*}{3 points } & $\begin{array}{l}\text { (Say) to the king, } \\
\text { the/my lord, (and) } \\
\text { the/my Sun }\end{array}$ & $\begin{array}{l}\text { Ugarit (EA 45, 49); Amurru (60-61, 159); Byblos (EA 85, 103-4, 124, } \\
\text { 132, 139-40); Jerusalem (EA 288); Shechem (253-54); Tyre (EA 146, } \\
\text { 155); Megiddo (EA 242, 244, 246, 365); Pella (EA 255) }\end{array}$ \\
\hline & $\begin{array}{l}\text { Say to the king, my lord, } \\
\text { the Sun from the sky }\end{array}$ & Akko (EA 232-34) \\
\hline & $\begin{array}{l}\text { Say to the king, my lord, } \\
\text { Sun of all countries }\end{array}$ & Byblos (EA 84, 138) \\
\hline & $\begin{array}{l}\text { To the king, my lord, } \\
\text { the breath of my life }\end{array}$ & Beirut (EA 142-43) \\
\hline & $\begin{array}{l}\text { Say to the king, my lord, } \\
\text { my personal god }\end{array}$ & Kumidi (EA 198) \\
\hline \multirow[t]{7}{*}{4 points } & $\begin{array}{l}\text { (Say) to the king, my lord, } \\
\text { my god, my sun }\end{array}$ & $\begin{array}{l}\text { Hasi (EA 175; 185; 186); Amurru (EA 156-57, 165, 168); Ginti-Kirmil } \\
\text { (EA 266); Qiltu (EA 278-80, 282-83, 366); Tyre (EA 147-50, 152); } \\
\text { Megiddo (EA 243); Gezer (EA 267-71, 292-94, 297) }\end{array}$ \\
\hline & $\begin{array}{l}\text { To the Sun, the king, my } \\
\text { lord, the king of Egypt }\end{array}$ & Nuhasse (EA 51) \\
\hline & $\begin{array}{l}\text { To the Great King, my } \\
\text { lord, my god, my Sun }\end{array}$ & Amurru (EA 160-61) \\
\hline & $\begin{array}{l}\text { Say to the king, my lord, } \\
\text { both Sun and my god }\end{array}$ & Ruhizza (EA 192) \\
\hline & $\begin{array}{l}\text { Say to the king, my lord, } \\
\text { my god, the Sun from the } \\
\text { sky }\end{array}$ & Yursa (EA 315) \\
\hline & $\begin{array}{l}\text { To the king, my Sun, } \\
\text { my god, my gods }\end{array}$ & Tyre (EA 151) \\
\hline & $\begin{array}{l}\text { Say to the king, my lord, } \\
\text { my Sun, my god, the } \\
\text { breath of [my] life }\end{array}$ & Qiltu (EA 281); Beirut (EA 141); Sidon (EA 144) \\
\hline 5 points & $\begin{array}{l}\text { Say to the king, my lord, } \\
\text { my Sun, my god, (and) } \\
\text { the/my Sun from the sky }\end{array}$ & $\begin{array}{l}\text { Akko (EA 235); Gezer (EA 298-300, 378); Yursa (EA 314, 316); Ashkelon } \\
\text { (EA 320-26); Lachish (EA 328-29, 331) }\end{array}$ \\
\hline
\end{tabular}




\section{TABLE 2}

\section{Second Section of the Greeting Formula}



Kumidi (EA 198); Pella (EA 255) 
Message of X, (the ruler of GN), your servant, the servant of the king and

the dirt at his/your feet and the ground on which he/you tread(s) on

Message of X, your

servant, the dirt at your

feet and the ground you

tread on, the chair you sit

on and the footstool at

your feet

Message of X, your servant and the mud under your feet, a dog

of the house of the king, my lord

Message of X, your servant, I am the dirt under the sandals of the king, my lord, and the king is the Eternal Sun

Message of $\mathrm{X}$, the ruler of GN, your servant,

the dirt under the feet

of the king, my lord, my god, my Sun, the ground he treads on
Qiltu (366); Akko (233-34, similarly 232)

Damascus (EA 195)

Amurru (EA 61)

Tyre (EA 155)

Hasi (EA 185) 


\section{TABLE 3}

Third Section of the Greeting Formula

\begin{tabular}{|c|c|c|}
\hline \multirow[t]{3}{*}{1 point } & $\begin{array}{l}\text { We fall at the feet of } \\
\text { my lord }+ \text { greeting }\end{array}$ & Tunip (EA 59) \\
\hline & $\begin{array}{l}\text { I fall at the feet of } \\
\text { (the king,) my lord }\end{array}$ & $\begin{array}{l}\text { Nuhasse (EA 51); Ruhizza (EA 191); Hazor (EA 227); Shechem (EA 252); } \\
\text { Ginti-Kirmil (EA 265) }\end{array}$ \\
\hline & $\begin{array}{l}\text { I fall at the feet of the } \\
\text { king, my sun, my lord } \\
+ \text { greeting }\end{array}$ & Ugarit (EA 49) \\
\hline \multirow[t]{2}{*}{2 points } & $\begin{array}{l}\text { I fall at the feet of my } \\
\text { lord } 7 \text { times }\end{array}$ & Qatna (EA 55) \\
\hline & $\begin{array}{l}\text { I fall at the feet of my } \\
\text { lord, my storm-god, } \\
7 \text { times }\end{array}$ & Qatna (EA 52) \\
\hline \multirow[t]{3}{*}{3 points } & $\begin{array}{l}\text { I/We fall at your/the } \\
\text { feet (of the king, my/our } \\
\text { lord,) } 7 \text { times and/plus } \\
7 \text { times }\end{array}$ & $\begin{array}{l}\text { Ugarit (EA 45); Qatna (EA 53); Hazor (EA 228); Damascus (EA 194, 196); } \\
\text { Irqata (EA 100); Hasi (EA 185); Amurru (EA 60, 63, 156-57, 165); Byblos } \\
\text { (EA 91, 94, 106, 122, 132, 136); Kumidi (EA 198); Jerusalem (EA 285-90); } \\
\text { Shechem (EA 253); Ginti-Kirmil (EA 264); Qiltu (EA 279); Beirut (EA } \\
\text { 142-43); Tyre (EA 146-51, 153-55); Pella (EA 255); Gezer (EA 271, 300) }\end{array}$ \\
\hline & $\begin{array}{l}\text { I fall at the feet of my/ } \\
\text { the lord, my/the Sun, } \\
7 \text { times and/plus } 7 \text { times }\end{array}$ & $\begin{array}{l}\text { Kadesh (EA 189); Byblos (EA 68, 74-76, 78-79, 81, 83-85, 89-90, 92, } \\
103-5,107-9,112,114,116-17,119,121,123-25,130,140\end{array}$ \\
\hline & $\begin{array}{l}\text { I fall beneath the feet of } \\
\text { my lord } 7 \text { times and } \\
7 \text { times }\end{array}$ & Byblos (EA 126, 129, 137, 138, 362) \\
\hline \multirow[t]{6}{*}{4 points } & $\begin{array}{l}\text { I fall/prostrate myself at } \\
\text { the feet of the king, my } \\
\text { lord and my Sun } 7 \text { times } \\
\text { and } 7 \text { times }\end{array}$ & Hasi (186); Shechem (EA 254); Megiddo (EA 242, 244, 246, 365) \\
\hline & $\begin{array}{l}\text { I fall at the feet of my } \\
\text { lord, my god, [and] my } \\
\text { Sun } 7 \text { times and } 7 \text { times }\end{array}$ & Amurru (EA 160, 161, 168) \\
\hline & $\begin{array}{l}\text { I fall at the feet of the } \\
\text { king, my lord, the Sun of } \\
\text { the dawn (over peoples) } \\
7 \text { times plus } 7 \text { times }\end{array}$ & Damascus (EA 195) \\
\hline & $\begin{array}{l}\text { I fall at the feet of the } \\
\text { king, my lord. I fall at the } \\
\text { feet of the king, my lord, } \\
7 \text { times and } 7 \text { times more }\end{array}$ & Qiltu (EA 283) \\
\hline & $\begin{array}{l}\text { I indeed prostrate myself } \\
\text { at the feet of the king, my } \\
\text { lord, the Sun from the sky } \\
7 \text { times and } 7 \text { times }\end{array}$ & Ashkelon (EA 321); Lachish (EA 329) \\
\hline & $\begin{array}{l}\text { I fall down in the dirt } \\
\text { under the feet of the king, } \\
\text { my lord, } 7 \text { times and } 7 \\
\text { times }\end{array}$ & Hasi (EA 175) \\
\hline
\end{tabular}


4.5 points I fall/prostrate myself at the feet of the king, my lord, my god, my Sun 7 times and 7 times

I fall at the feet of the king, my lord, both Sun and my god, 7 times and 7 times

Before the king of all countries, Great King, at the feet of my lord, my Sun, I fall 7 times and 7 times

I fall at the feet of the king, my lord, my Sun, my god, the breath of my life, 7 times and 7 times

5 points (Truely) I (indeed) fall/ prostrate myself at the feet of the king, my lord, the Sun from the sky, 7 times and 7 times (both) on the stomach and on the back

I (indeed) fall/prostrate myself at the feet of [the king] my lord 7 times and 7 times (both) on the stomach and on the back

I indeed prostrate myself at the feet of the king, my lord, my god, my Sun, the Sun from the sky, 7 times and 7 times, on the back and on the stomach

I fall at the feet of the king, my lord, 7 times and 7 times, here and now, both on the stomach and on the back at the feet of the king, my lord

I fall at the feet of the king, my lord. I fall 7 times and 7 times more, both on the stomach and on the back

I prostrate myself at the feet of the king, my lord, my god, the Sun from the sky, 7 times and 7 times, both on the stomach and on the back
Amurru (EA 159); Ginti-Kirmil (EA 266); Qiltu (EA 278, 280); Tyre (EA 152); Megiddo (EA 243); Akko (EA 235); Gezer (EA 267-70, 292-94, 297)

Ruhizza (EA 191)

Byblos (EA 88)

Beirut (EA 141); Sidon (EA 144)

Qiltu (EA 366); Akko (EA 232, 234); Gezer (EA 298); Ashkelon (EA 322)

Qiltu (EA 281-82, 335); Ashkelon (EA 320, 323-26); Yursa (EA 315)

Lachish (EA 328, 331); Gezer (EA 378); Yursa (EA 314, 316)

Qiltu (EA 284)

Akko (EA 233) 
TABLE 4

GREETING-FORMULA RANKINGS ( 1 = low; 5 = high)

\begin{tabular}{|c|c|}
\hline \multicolumn{2}{|c|}{ NORTHERN PERIPHERY } \\
\hline Tunip & 1.6 \\
\hline Hazor & 1.7 \\
\hline Qatna & 1.8 \\
\hline Irqata & 2 \\
\hline Ugarit & 2.2 \\
\hline Nuhasse & 2.3 \\
\hline Kadesh & 2.3 \\
\hline Damascus & 2.4 \\
\hline Ruhizza & 2.6 \\
\hline Byblos & 2.7 \\
\hline Amurru & 2.9 \\
\hline Kumidi & 3.7 \\
\hline Hasi & 3.8 \\
\hline \multicolumn{2}{|c|}{ SOUTHERN HILl COUNTRY } \\
\hline Jerusalem & 2 \\
\hline Shechem & 2.7 \\
\hline Ginti-Kirmil & 2.7 \\
\hline Qiltu & 3.8 \\
\hline \multicolumn{2}{|c|}{ PHOENICIA AND NoRTHERn CANAAN } \\
\hline Tyre & 3 \\
\hline Megiddo & 3.1 \\
\hline Sidon & 3.3 \\
\hline Beirut & 3.4 \\
\hline Pella & 3.7 \\
\hline \multicolumn{2}{|c|}{ COASTAL CANAAN AND SHEPHELAH } \\
\hline Gezer & 4 \\
\hline Akko & 4.45 \\
\hline Yursa & 4.6 \\
\hline Lachish & 4.8 \\
\hline Ashkelon & 5 \\
\hline
\end{tabular}

make matters even more complicated, some of these same frontier polities were also claimed by yet another great power of the day, the Mitanni kingdom of northern Iraq and Syria. Because of their physical distance from the Nile Valley and because they served a valuable function as a buffer zone between the core of Egypt's northern empire and threatening rival kingdoms, it appears that the rulers of these march lands were granted the right to utilize exceptionally high-status greeting formulas without admonishment (their composite scores range from 1.6 to 2.3$).^{3}$

Vassals of polities located in the vicinity of Kadesh, the strategically vital town that served throughout the New Kingdom as a flashpoint for military engagement, may not have been so leniently treated. The rulers of Kadesh, Amurru, Byblos, Damascus, and Ruhizza had greetings that scored between 2.3 and 2.9 on the scale of obsequiousness. At different periods, however, the greeting formulas utilized by certain of these kings ranged from quite bold (see especially EA 191 for Ruhizza; EA 171 for Amurru; EA 194 for Damascus) to elaborately effacing (for example, EA 192 for Ruhizza; EA 168 for Amurru; EA 195 for Damascus). While the dramatic highs and lows of these letters may reflect changing historical circumstances-as Egyptian and Hittite troops and their local allies moved in and out of the region, it may also have been more important to the Egyptians to strictly regulate greeting formulas in a region that the imperial government wished to make com-

pletely clear-to vassals and foes alike-belonged to Egypt. Certainly the vassal from Ruhizza vastly increased the quotient of honorifics due to the pharaoh and referred to himself as the dirt at the feet of the king right after having received a royal letter, which perhaps admonished him for assuming liberties above his rank in professing to fall only once at the feet of his sovereign.

The nature of the imagined prostration of the vassal before the pharaoh is one of the most important features that distinguishes the introductions utilized by the northernmost frontier

\footnotetext{
3 Despite its more southerly locale, the city of Hazor was undoubtedly included in this same obsequiousness
}

range due to the fact that it was by far the largest citystate in Late Bronze Age Canaan. 




FIG. 1.-Map shows the spatial distribution of cities with similar greeting formulas 
vassals from those found in the corpus as a whole. While the vast majority of the individuals writing to Egypt claimed to fall before the feet of the Egyptian king seven times and seven times, only rulers from the northern frontier and the hill country of Canaan simply fell at the feet of the pharaoh (EA 49, 51, 59, 191, 227, 252, 265) or fell at his feet only seven times (EA 52, 55). Another obvious mark of status, the right to exchange expressions of well-wishing with the pharaoh and his family, is narrowly restricted to the northern polities (see, for example, EA 45, 49, 59, 75, 92, 132, and 137-38). Such courteous and courtly introductions, on the other hand, constitute an indispensable component of the correspondence between Great Kings.

Given the confidence in their own status inherent in the manner in which particularly the farthest-flung vassals addressed the pharaoh, it is perhaps not surprising that they also felt justified in soliciting from him special personages and perquisites. The ruler of Ugarit, for example, requested two Nubian palace attendants and a physician (EA 49). Likewise, the ruler of Qatna asked his liege for a sack of gold in order to fashion a new statue of the god Shimigi (EA 55). Given that the Hittites had stolen the old statue, the vassal was almost certainly implying with his request that the receipt of this sack of gold would, in actual fact, purchase Qatna's continued political loyalty. The gold and silver sent by the pharaoh to Aziru of Amurru (EA 161), who was also actively courted by the Hittites, may similarly have served as an incentive for a vulnerable vassal to stay loyal. These presents, perhaps too little given too late, were not to alter the fact that virtually all of these northern polities would defect to the Hittite empire prior to Akhenaten's death.

Finally, with regard to the high-status greeting formulas of the northern vassals, it is significant that the vast majority of the rulers in these contested locales had only intermittent contact with the Egyptian government via circuit officials who carried letters or-much more infrequently - troops into their regions. The exception to this rule is the city of Kumidi, which for a short period during the reign of Akhenaten had a resident governor as well as the local leader. Indeed, this eventual cohabitation with the Egyptian administration may perhaps explain Kumidi's status ranking of 3.7, which along with that of the nearby war-torn town of Hasi, is by far the humblest of all the northern polities. As the greetings utilized by vassals from the coastal lowlands of Canaan demonstrate, close proximity to Egyptian administrators was invariably detrimental to local rights and autonomy.

\section{Hill Country}

The grouping of vassals ranked next highest in status after the territories at the northern extremity of Egypt's empire are the cities of the Canaanite hill country-which is somewhat surprising as this area is located in close proximity to the traditional core of Egypt's authority in Syria-Palestine, namely, the Via Maris trunk route and the surrounding coastal lowlands of Canaan. Located in this sparsely populated, mountainous area, Jerusalem, GintiKirmil, Shechem, and Qiltu appear to have spent most of the decades chronicled in the Amarna letters engaged in internecine battles and in military actions against the neighboring cities of the plains. At one time or another accusations of treachery by other rulers (see, for example, EA 246, 280, 289-90) or by the Egyptian government (EA 253-54, 286) are levied at nearly all of these mountain warlords, indicating that, like the northern vassals, these men could not always be counted upon to act in Egypt's best interest. 
Indeed, this area seems always to have lain just beyond the reach of firm imperial control, and archaeologically it adhered to traditional communal cave burial long after most of Canaan had adopted the more Egyptianized custom of burying the dead in single graves. ${ }^{4}$ Significant also is the fact that not one of these cities appears on the topographic lists compiled by New Kingdom pharaohs to chronicle their triumphs in battle. Thus it appears that the rulers of these mountain strongholds may well have voluntarily assumed their status as vassal kings - and this, in turn, would likely have influenced the treatment accorded their territory by the Egyptians.

Interestingly, on one occasion each, the rulers of Shechem (EA 252) and Ginti-Kirmil (EA 265) evoked the highest-status genuflection open to a vassal, namely, falling at the feet of the pharaoh only once. More typically, however, the greetings from rulers of this region are of the standard, unadorned variety. Each and every letter sent by the king of Jerusalem, for example, opens, "Say to the king, my lord. Message of Abdi-Heba, your servant. I fall at the feet of the king, my lord seven times and seven times" (EA 285-90). The fact that Abdi-Heba's letters are relatively free from unctuous epithets and the like may have to do with his perceived status as a "friend of the king" (EA 288). Certainly, from his royal friend the vassal felt free to request, "much food, much oil, (and) much clothing" (EA 287).

Tagi, the ruler of Ginti-Kirmil, also may have had an especially elevated status, as he received as a present from the Egyptian king a gold goblet and twelve sets of linen garments (EA 265). Further, Tagi is unique among the hill country vassals in reciprocating with a personal gift to the king (EA 266). After an elaborate hymn in honor of the pharaoh and his own loyalty toward his personage, Tagi dispatched to him a harness for a pair of horses, a bow, a quiver, and a spear. Such a gift is otherwise unattested outside the bailiwick of the northern vassals, and one might be tempted to assume from this that the two men enjoyed a personal bond, perhaps forged during Tagi's probable tenure at court as a youth. ${ }^{5}$ Significantly, however, a recent find at Beth Shan of a very small and easily concealable letter, sent from Tagi to an alleged partner in treason, ${ }^{6}$ suggests that the gifts and his elaborate protestations of loyalty served as smoke screens for seditious activity.

It should be noted that at 3.8 Qiltu is significantly lower in rank than the other cities in the hill country, which mostly overlap in status rankings with the polities near Kadesh. The fact that Qiltu faced both a war against thirty allied towns as well as an internal revolution (EA 271, 279-84, 287, 289, 366), however, may have made it less secure than its compatriots in its own autonomy. In addition, if Qiltu is to be identified with modern Hebronas is generally thought ${ }^{7}$-it would have been the closest of the hill cities to the Shephelah and the Egyptian centers of control in the coastal lowlands.

\footnotetext{
${ }^{4}$ R. Gonen, Burial Patterns and Cultural Diversity in Late Bronze Age Canaan (Winona Lake, Indiana, 1992), pp. 34-38.

${ }^{5}$ For the Egyptian practice of raising heirs to vassal thrones at the Egyptian court, instituted by Thutmose III, see K. Sethe, Urkunden der 18. Dynastie IV (1914; Leipzig, 1984), p. 690: 2-5, and E. Feucht, "Kinder fremder Völker in Ägypten," Studien zur altägyptischen
}

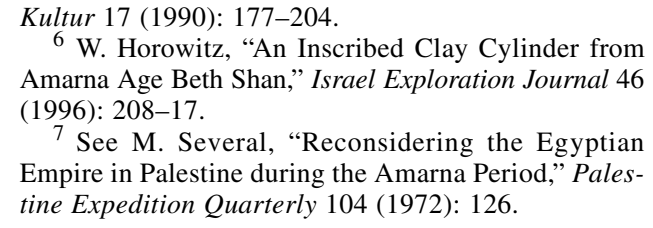

${ }^{6}$ W. Horowitz, "An Inscribed Clay Cylinder from Amarna Age Beth Shan," Israel Exploration Journal 46 (1996): 208-17.

7 See M. Several, "Reconsidering the Egyptian Empire in Palestine during the Amarna Period," Palestine Expedition Quarterly 104 (1972): 126. 


\section{The Phoenician Coast and Northern Canaan}

The cities of Beirut, Sidon, Tyre, Megiddo, and Pella—all located either on the Phoenician coast or in northern Canaan-make up the third cluster of cities, and they are characterized by particularly deferential greeting formulas. This style of address typically consists of three or four titles accorded the king. He is, for instance, "the king, my lord, my Sun" (as in EA 242, 255, 365) or "the king, my lord, my god, my Sun" (EA 147-50, 243). Likewise the sender may qualify himself as "the loyal servant of the king" (EA 242-44, 365) or, more humbly, as "the dirt under the feet and sandals of the king" (EA 146-47, 154). The prostrations before the pharaoh, however, remain the standard seven times and seven times.

This zone of cities appears to have been unclaimed by other great powers of the day and so to have resided within the core of the Egyptian empire. The rulers are likewise known to have taken on much of the responsibility for the administrative maintenance of the empire. The ruler of Beirut, for instance, at times disbursed grain from the nearby state granary at Yarimuta (EA 85, 105, 114). Vassals located at Megiddo and other Jezreel Valley towns were charged with furnishing corvée workers to till Egyptian-owned fields and to work at yet another state granary at Joppa (EA 365). Further, the rulers of Beirut, Sidon, and Tyre are all stated to have "done service" with ships docked at their ports (EA 155).

With regard to Tyre, some argue that this island polity may even have been dedicated to the estate of the eldest daughter of Akhenaten. ${ }^{8}$ Indeed, the ruler of Tyre refers to himself as a "palace attendant" rather than as a "mayor" (EA 151) and expresses-in his evocations of the pharaoh's "powerful arm" (EA 147) and "sweet breath" (EA 146, 147)—a demonstrable familiarity with Egyptian phraseology and court etiquette. Abi-Milku's conversance in Egyptian manners is perhaps best explained in light of the pharaonic practice of raising the heirs of core Syro-Palestinian vassals at the Egyptian court. Not only did this custom serve to Egyptianize the future vassal leadership, but it meant that Egypt very neatly procured for itself a steady supply of high-status political prisoners. Awareness of the potential fate of such loved ones must indeed have kept many vassals painfully polite.

\section{The Coastal Lowlands of Canaan and the Shephelah}

If the varying levels of obsequiousness expressed in the Amarna letter greetings may be taken as a general indicator of the strength of imperial control in a particular region, Egypt had the cities of Akko, Gezer, Lachish, Yursa, and Ashkelon grasped tightly by the hair. To these rulers, the pharaoh was "their king, their lord, their Sun, their god and the Sun from the sky" (EA 235, 298-300, 331), while they themselves were "the dirt at his feet and the groom of his horses" (EA 320-21, 316, 328) or "the ground upon which he treads" (EA 233-34). Finally, when these rulers prostrated themselves, they did so mostly seven times and seven times, on the stomach and on the back. Qiltu, the hill-country city nearest to this area, is the only other locale to offer such a humble prostration.

\footnotetext{
${ }^{8}$ Frequent evocations of Meritaten-and Tyre as the city of Meritaten-in EA 155 are at the crux of the matter. For references to the numerous authors who argue this point, see my The Architecture of Imperi-
}

alism: Military Bases and the Evolution of Foreign Policy in Egypt's New Kingdom (Leiden and Boston, 2005), p. 246, n. 113. 
The locales of Ashkelon, Yursa, and Lachish almost certainly dictated their subservience, as these cities were situated on the southernmost border of Egyptian-held Sinai and Canaan. Indeed, Yursa lay only $10 \mathrm{~km}$ from the main Egyptian administrative center at Gaza—and both Yursa and Ashkelon could be reached from Gaza in an easy day's march. A mounted messenger from Gaza could likewise arrive at Lachish in the course of a day, and in the Amarna period this city seems to have functioned under the close watch of an Egyptian official named Paapu (EA 333). Further, it is notable that the foundation deposits of the second incarnation of the fosse temple at Lachish strongly suggest that Amenhotep III wholly or partially sponsored its construction..$^{9}$ Interestingly, in the Twentieth Dynasty the main temple at Lachish seems to have been utilized by the Egyptians as a center for tax collection, ${ }^{10}$ and it is thus possible that Amenhotep III's temple earlier served the same purpose.

While the proximity of Ashkelon, Yursa, and Lachish to Egypt's border and main base at Gaza likely had to do with the subservience expressed in the Amarna-letter greetings, the extremely tight rein kept on Gezer and Akko may have had more to do with the strategic importance of their locales. The Bay of Akko, for instance, was quite likely a fully stocked Egyptian naval base from the reforms of Thutmose III onward-as it is the closest harbor of good quality to Egypt. Likewise, Gezer guards one of the few relatively easy passes into the hill country and on to the trade routes beyond. It, like Lachish, was notable for the quantity of small objects that archaeologists discovered bearing Amenhotep III's name. ${ }^{11}$ A fragment of a monumental hieroglyphic inscription carved on a stone building block at Gezer indicates that the site served as an administrative headquarters in the Nineteenth Dynasty, and Dever has proposed that an Amarna period residency may perhaps be present in his field VI. ${ }^{12}$ As gateways between the Via Maris and the sea, on the one hand, and the Via Maris and the hill country, on the other, then, it is likely that Akko and Gezer were kept under the especially close supervision of the Egyptian government. Judging from their groveling greeting formulas, however, such intimacy with Egyptian officialdom did nothing to enhance the respect these rulers enjoyed.

\section{IMPLiCATIONS FOR Egyptian Diplomacy}

That the rulers of each city-state were allowed a specific range of greeting formulas divvied out according to their perceived rank in the empire cannot confidently be asserted. There are certainly variations in formulas from letter to letter sent by the same vassal, often correlating with the degree of urgency communicated. What is interesting, however, is that each geographic area maintained a generally consistent ranked level of obsequiousnessdespite the occasional change of ruler or variation in political fortune. The kings of the northern frontier and those of the coastal lowlands of Canaan, for example, employed mutually exclusive greeting formulas, and one expects that the nature and number of their

\footnotetext{
${ }^{9}$ See O. Tufnell, C. H. Inge, and G. Lankester Harding, Lachish II (Tell ed-Duweir): The Fosse Temple (New York, 1940).

${ }^{10}$ See the discussion and literature cited in my Architecture of Imperialism, pp. 769-70.

${ }^{11} \mathrm{~J}$. Weinstein, "Egypt and the Levant in the Reign
}

of Amenhotep III," in D. O'Connor and E. Cline, eds., Amenhotep III: Perspectives on His Reign (Ann Arbor, Michigan, 1998), p. 233.

12 W. G. Dever, "Gezer," in E. Meyers et al., eds., The Oxford Encyclopedia of Archaeology in the Near East, vol. 2 (New York, 1997), p. 398. 
respective imagined prostrations would in fact be consistent with those performed in reality if the vassal were granted an audience with the king. ${ }^{13}$ The rest of the Levant exhibited a less stark division of formulas; yet the cities in the southern hill country, with the exception of Qiltu, utilized consistently higher-status greeting formulas than those used on the Phoenician coast and in northern Canaan. What, then, can this tell us?

There is the seductively simple explanation that each polity in the Egyptian empire was intuitively aware of just how much it could get away with - due to the formidable nature of its terrain or its distance from the core of the empire. It is worthwhile, however, to explore a further possibility. It is a general principle cross-culturally in empires past and present that considerations of cost have a role to play in dictating foreign policy. Thus if a king wishes to obtain sovereignty over a strategic area that lies at the far borders of his empire, he might attempt to woo this area into his sphere of influence with the promise of special privileges. The military alternative is not only expensive with regard to such a far-flung campaign, but it could also potentially backfire if the desired polity allied itself with a competing great power for protection (and, indeed, we know that the defection of former vassals to Hittite overlordship was an ever-pressing problem for the Egyptians during the Amarna period). Likewise, with regard to areas that are traditionally difficult to subdue and, furthermore, provide little in the way of extractable wealth — such as mountain rangesan empire might launch many campaigns against individual strategically placed, fortified towns, or it could use more diplomatic (and less wasteful) means to achieve its desired ends.

For some empires, such as that of the Hittites, this problem was solved by the preparation of many individual treaties, each tailored to the particular nuances of the political relationship, as expounded in the treaty's historical prologue. Privileged areas or protectorates, while maintaining a vassal status, were granted special perquisites-such as exemption from certain obligations or from taxation. These concessions, however, were also granted on a more symbolic plane. Thus the king of Kizzuwatna was required to come before the Hittite king and "look upon the face of His Majesty." The treaty also stipulated, however, that, "As soon as he comes before His Majesty, the noblemen of His Majesty 〈will rise〉 from their seats. No one will remain seated above him" (CTH 41). ${ }^{14}$

Certainly, we know from the Amarna archive that seemingly small matters concerning rank and status, such as greeting formulas or physical position at a ceremony, were taken very, very seriously. For example, in one letter, the Hittite king upbraids Akhenaten roundly for a perceived insult lodged in the greeting formula of a letter that the pharaoh had sent to him. The Hittite monarch writes,

And now, as to the tablet that [you sent me], why [did you put] your name over my name? And who (now) is the one who upsets the good relations [between $u s]$, and is su[ch conduct] the accepted

\footnotetext{
${ }^{13}$ New Kingdom art is rife with depictions of foreigners in various attitudes of submission. For differing postures that appear linked specifically to status, see, for example, the rulers of Kush and Wawat in the tomb of Huy. In this case, the artist has also carefully differentiated the types of tribute offered by both and makes it clear that it is only the rulers of Wawat who bring their children to court; see N. de Garis Davies and A. H. Gardiner, The Tomb of Huy, Viceroy of Nubia
}

in the Reign of Tutánkhamûn (no. 40), The Theban Tomb Series, 4th Memoir (London, 1926), pl. 27.

${ }_{14}$ Translation in G. Beckman, Hittite Diplomatic Texts (Atlanta, 1996), p. 15. For a discussion of status differentiation in Near Eastern vassal treaties, see D. J. McCarthy, Treaty and Covenant: A Study in Form in the Ancient Oriental Documents and in the Old Testament (Rome, 1963), pp. 22-23. CTH = E. Laroche, Catalogue des textes hittites (Paris, 1971). 
practice? My brother, did you write [to me] with peace in mind? And if [you are my brother], why have you exalted [your name], while I, for [my part], am tho[ught of as] a [co]rpse (EA 42).

Clearly, even among Great Kings, the seeming niceties of greeting formulas were in fact highly loaded with symbolic projections of status that-if not agreed upon by both partiesmight evoke a violent reaction.

Yet another near diplomatic debacle was incurred by virtue of the fact that Amenhotep III apparently failed to make a physical distinction at a public ceremony between the chariots belonging to Babylonian envoys and those belonging to Egypt's own vassals. The Babylonians dutifully reported this to their king, who wrote back infuriated, saying "(You) put my chariots among the chariots of the mayors. You did not review them separately. You humiliated them before the country where you are. You did not rev〈iew $\rangle$ (them) separately" (EA 1). According to the nature of Egypto-Babylonian relations, Amenhotep III should certainly have publicly acknowledged that the Babylonians were not his vassals but were instead emissaries from a Great King of equal status. Indeed, such an insult cannot be written off as naiveté on the part of the Egyptians, for a deep concern with spatially segregating important individuals according to their status is illustrated by a description of Amenhotep III's last Heb Sed. At this festival, as was surely traditional, all the luminaries of the land gathered and, "rewards were given out in the form of the gold of praise, and ducks and fish of gold, and they received ribbons of green linen, each person being made to stand according to his rank" (Urk. IV, 1867: 7-9).

The Hittite treaties, which could on occasion stipulate such niceties as the manner in which a particularly favored vassal was to be received by the retinue of his overlord, consisted of a sworn oath and a written tablet-both covering the same material. It is known that the Egyptians, for their part, required an "oath of the lord" from foreign rulers whom they desired to be "on their water," as they put it, as well as at times a $s d f$ tryt oath, in which a vassal seems to have promised never (or never again) to rebel on pain of stipulated penalties. It was this latter type of oath that Thutmose III required his newly won vassals to swear following their defeat and submission at Megiddo (Urk. IV, 1235: 16) and that Amenhotep II later elicited from the king of Kadesh and his family (Urk. IV, 1304:2). ${ }^{15}$

Now such a $s d f 3$ tryt oath may perhaps be parroted in a letter from the king of Tyre, when he states to the pharaoh,

Whoever gives heed to the king, his lord, and serves him in his place, the Sun com〈e $\rangle$ s forth over him, and the sweet breath comes back from the mouth of his lord. If he does not heed the word of the king, his lord, his city is destroyed, his house is destroyed, never (again) does his name exist in all the land. (But) look at the servant who gives heed to 《to» his lord. His city prospers, his house prospers, his name exists forever" (EA 147).

Unless the king of Tyre had a particularly good memory, one might assume that such potential penalties had in fact been written down for his benefit. Indeed, although this passage is recorded in a recognizably Egyptian form of legalese, it sounds remarkably close in purpose to a clause in a treaty between Mursili II and a ruler of Amurru named Tuppi-Teshshup. "If Tuppi-Teshshup [does not observe these words] of the treaty and of

${ }^{15}$ For discussions of the "oath of the Lord" and
the $s d f 3$ tryt oath, see especially J. Wilson, "The
Oath in Ancient Egypt," JNES 7 (1948): 129-56, and

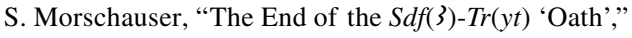
Journal of the American Research Center in Egypt 25 (1988): 93-103. 
the oath, then these oath gods shall destroy Tuppi-Teshshup, [together with his person], his [wife], his son, his grandsons, his household, his city, his land, and together with his possessions" (CTH 62). ${ }^{16}$

References to spoken oaths in the Amarna archive are not difficult to find. For instance, in one case, the ruler of Shechem bitterly complains to the pharaoh because a city under his control was seized, although this violated the peace agreement that the ruler of Shechem and the Egyptian governor had sworn together as an oath (EA 252). Likewise, the ruler of the northern polity of Nuhasse refers back to an instance a century or so before when Thutmose III had first poured oil on the head of the ruler's ancestor and uttered the following proclamation: "Whom the king of Egypt has made a king, [and on whose head] he has put [oil ], [no] one [shall] (lacuna)" (EA 51). The ruler of Nuhasse then states that the Hittite king had recently been writing to him with offers of an alliance. He informs the pharaoh, "My lord, [I rejected] (the offer of ) tablets of treaty obli[gations], and [I am (still) a servant of] the king of Egypt, [my lord]" (EA 51).

Now, the contents of this last letter would seem to equate the two ceremonies of anointing and swearing an oath, on the one hand, with that of the formulation of a treaty, on the other. Indeed, in both Akkadian and Hittite legal documents, treaties were referred to by a pair of terms meaning literally "binding" (riksu/rikiltu and išhiul) and "oath" (māmìtu and lingai $):{ }^{17}$ and a treaty could even be designated as "the tablet of the oath." ${ }^{18}$ It is thus highly significant that Ramesses II quite consciously and consistently in correspondence made reference to his treaty with Hattusili III as an oath rather than as a treaty. For example, when Ramesses wished to reassure Hattusili that despite his patently propagandistic renditions of the Battle of Kadesh, he was in fact a good treaty partner, he stated, "See, the Great Gods of our lands, they are witness to the word of the oath, which we have made. Further: I have not set aside the oath. I have obeyed the oath. And I will adhere closely to it, the peace and the brotherhood" (CTH 156). ${ }^{19}$ In this context, it is the words of the oathand not the document that recorded them-that are invoked.

Similarly illuminating is a letter from Ramesses II to the ruler of Mira-Kuwaliya, who had apparently questioned his fidelity to the Egypto-Hittite treaty. Ramesses writes:

Another thing: What is this matter which the Great King, the King [of Hatti], writes $\langle$ me $\rangle$ about, and which you write [me] about? The written version of the oath which [I made] for the Great King, the King of Hatti, my brother, has been set at the feet of [the Storm-god] and before the Great Gods. They are the witnesses [to the words of the oath]. And the written version of the oath which the Great King, [the king of Hatti, my brother], made for me [has been set] at the feet of the Sun-god of [Heliopolis] and before the Great Gods. They are the witnesses to the words [of the oath]. I have taken the oath and will not abandon it. In your heart, [do] not [trust] in the false words which you have heard. There is no sense in it. I am thus forever in the [good] relationship [of brotherhood] and peace in which I stand together with the Great King, [the King of Hatti, my brother] (CTH 166). ${ }^{20}$

This excerpt has been quoted at length as it confirms the fact that documents of which we possess evidentiary record and are accustomed to term "treaties" could and often were

\footnotetext{
16 Translation in Beckman, Hittite Diplomatic Texts, p. 59.

17 Ibid., p. 2.

18 Ibid., p. 20. For similar usages of "oath" together with or in place of "binding," see, for example, ibid.,
}

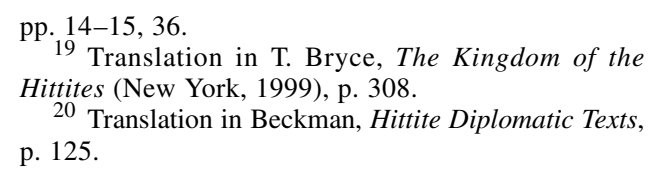


referred to by the parties who adhered to them simply as "oaths." It was thus the spoken word-dedicated to the gods-that was of primary importance, and the written covenant itself served only as the materialization and consultable confirmation of these words.

To date no Amarna period treaties have been uncovered, which has led many scholars to speculate that the Egyptians relied solely upon oral assurances of vassal loyalty within their own empire. The quotes from Ramesses II referring to his treaty with the Hittites as an "oath" strongly suggests that this idea needs to be rethought. Further, his letter to the ruler of Mira-Kuwaliya may shed light on the reason such treaties were not found together with the cache of diplomatic correspondence in the Office of the Letters of the Pharaoh. As the embodiment of oaths sworn before deities, who acted as witnesses and guarantors of these oaths, Egyptian treaties would have been stored in temple archives (or, indeed, if outstandingly prestigious, carved upon temple walls).

We know, certainly, that the Egyptians did draft documents of contract or agreement with their vassals. One admittedly debated example is the $n t^{-}{ }^{`}$ contracted between Thutmose III and the rulers of Lebanon in order to ensure that his northern harbor depots would be well stocked. Although some translate the phrase $n t^{-}$' as "custom" or "agreement," it is surely significant that $n t^{-}$' is the translation for "treaty" (riksu or rikiltu) in the Egyptian-language copy of the treaty drafted by Hattusili III and Ramesses II. ${ }^{21}$ Less ambiguous is an intriguing reference in EA 52 sent by the king of Qatna, who suggests to the pharaoh that he, "Inspect, my lord, his tablets. [He/you will find] the houses of Qatna belong to my lord a[lone]." Likewise, it is known from the prologue to the treaty between Ramesses and Hattusili that a written treaty between the Egyptians and the Hittites existed already in the Amarna period (KRI II, 228: 1-3), and so it is not absurd to propose that Egypt may have engaged in vassal as well as parity treaties at this time.

With or without such a document in hand, however, it is important to note that in the Amarna letters each of the traditional obligations included in an ancient Near Eastern treaty is evidenced multiple times. The letters bear witness to the obligation of vassals periodically to appear before the pharaoh, to send tribute regularly, to extradite fugitives, to subjugate their own foreign policy to that of the Egyptians, to contribute troops when requested, to send their heirs to Egypt for safekeeping, to protect the cities and representatives of the king, and to allow intercity feuds to be arbitrated by an Egyptian representative. That not all vassals were responsible for the exact same obligations, however, is a near certainty, and the possibility thus remains strong that treaties between Egypt and individual vassals may eventually be discovered, perhaps in temple archives. Were such documents to come to light, I suspect we would find that the Egyptians, like their Hittite counterparts, recognized in their treaties the old imperial adage that all vassals are most certainly not created equal.

${ }^{21}$ D. Redford, "The Hyksos Invasion in History and Tradition," Or., n.s., 39 (1970): 43, n. 1; see also D. Lorton, The Juridical Terminology of International Relations in Egyptian Texts through Dynasty XVIII (Baltimore, Maryland, 1974), p. 178. These $n t^{-}{ }^{\prime}$ con- tracts are mentioned in the eighth, thirteenth, fourteenth, and seventeenth campaigns (Urk. IV, 700: 6-9; 719: 7-11; 723: 4-9; 732: 6-8) and also implicitly in the seventh and ninth campaigns (Urk. IV, 694: 3-8; 707: 10-14). 